\title{
Marine Fish Production and Diversity Record from Sunda Strait Before Tsunami Disaster at 22 December 2018: Evidence from Ports in Banten Province, Indonesia
}

\author{
Yonvitner \\ Department of Aquatic Resources Management, Faculty of Fisheries and Marine Science and Director of \\ Disaster Research Centre. IPB University, Indonesia. Corresponding Author: Faculty of Fisheries and Marine \\ Science. Bogor Agricultural University. Indonesia \\ Surya Genta Akmal, Mennofatria Boer, Rahmat Kurnia \\ Department of Aquatic Resources Management, Faculty of Fisheries and Marine Science and Director of \\ Disaster Research Centre. IPB University, Indonesia \\ Ernik Yuliana \\ Department of Biology, Faculty of Mathematics and Natural Sciences, Universitas Terbuka, Jl Pondok Cabe \\ Raya, Pamulang, Tangerang Selatan 15418. Indonesia
}

\begin{abstract}
Pelagic and demersal species dominate in marine ichthyofauna in northern and southern of Banten Sea. Detail information about fish exploitation was collected directly from fishermen in four landing ports in the Banten Province (Indonesia). The data were collected in four landing ports such as Tangerang, Serang, Pandeglang, and Lebak district. The total number of recorded species was thirty in Tangerang, forty-two in Serang, thirty in Pandeglang and eighteen in Lebak. The dominant fish in Tangerang was demersal Upeneus sp.; Rastrelliger sp. in Serang, Sardinella sp. in Labuan and Euthynuss sp. in Lebak, all three referred as pelagic species. The area with the known best fish diversity had low productivity shown in data from Serang landing port. The differences in the number of species that were landed in every surveyed port have an influence on used fishing methods with an impact on sustainable exploitation of sea resources in the area of maritime Indonesia.
\end{abstract}

Keywords: Marine fish, Biodiversity, Java, Pelagic, Demersal

DOI: $10.7176 / \mathrm{JNSR} / 9-8-03$

Publication date: April $30^{\text {th }} 2019$

\section{INTRODUCTION}

The silent tsunami that follows an eruption of Anak Krakatao in struck several areas, Banten Province and Lampung Province. Tsunami effect to coastal community activity in Banten Province that dominant to economy aspect is fishing activity, farming in coastal line and tourism. But the main effect to the local community is fishing activity, where a part of local fishing activity closed more than two months. Banten has 3 fisheries management area (FMA) are Indian Ocean region in western Sumatera (code number 572), the Indian Ocean in Southern Java (code number 573), and western part of Java Sea (code number 712). The differences between FMA have significant fish diversity and habitat characteristic. The FMA 712 Java sea have character as shallow water, many small islands, and substrate than consist of mud until rubble and other for ship transportation.

In coastal area have many landing ports from the western area (in Banten Province) to Eastern (east java). The FMA 571 especially for Sunda Strait known as a transition area between Natuna Sea into the Indian Ocean in southern. Sunda strait also used as international seaway (ALKI) of an international public ship or national ship to enter the Indian ocean and vice versa to the South China Sea. In Sunda strait, we found any small islands are Sanghiang, Krakatao Island, Sebesi and etc, with sandy and rubble substrate. The Indian Ocean (FMA 572) dominant as an open sea and deep sea water which is sandy and ruble and also stone and rocky shore. This area is known and close relationships with EEZ in Bay Bengal large marine ecosystem and open sea in southern.

The occurrence of a tsunami due to the Krakatau eruption has affected the ecosystem and fisheries in the Sunda Strait coast. Disruption to fish biodiversity, fisheries business which includes ships, ports, markets, fisheries infrastructure, and fisheries processing businesses. The ecosystem and diversity relationship are important to predict the asses of sustainability potency of fish (Branc, 2008). The coastal habitat in 712 particularly mangrove, coral reef, and organic material and various activity influence to fish biodiversity. Small pelagic fish and demersal dominated of fishery production in every landing based.

Fishing activity in FMA 712, 572 and 573 potential to threat marine fish biodiversity. The FMA 572, 573, and 712 are increasingly under threat from human activity (Wrigh et al, 2015). Including impacted from sea transportation, sand mining in the sea, fishing, public and non-public port, communication line, and gas pipeline from Sumatera to Java island. In the future its potential to threaten the biodiversity and the sustainability of 
fisheries.

According to Farriols et al 2015, the exploitation of fish resources may cause decreasing and biodiversity loss. Traditionally, diversity may explain by richness, number species, size of the sample, and population and its production. Fish production close related to fisherman fleet and its operational technique and fish distribution in the ecosystem. Prediction of Worm et al (2009) that fishing activity is reducing of biodiversity of the sea worldwide Active fishing gear more potential cause decreasing of the population.

Species composition also explains the economic and non-economic group of fish from fisher. Catch composition also is shown by dominant species of total coastal. Risk all 2016 in the Mediterranean (Egypt) recorded the composition change increasingly from influence by seasonal production. Castelllo (2015) record that $94 \%$ of MPA allow fishing, that means the low capacity of regulation to protect the exploitation intensity.

Banten fisheries are the best view fisheries that as representative of fisheries in 3 different of FMA. The fishing activity dominated by artisanal fisheries or small scale fisheries. Worm et al (2006) conclude that longterm fisheries capacity decrease to serve human need to food and potential to decreasing biodiversity effect to global fisheries and marine ecosystem fisheries. Similarly with Indonesia. The fish's biodiversity is important to future and sustainability management. Therefore research and spatial map and distribution needed to focusing and as basic data for the management program.

The aim of this research is to evaluate of fishing ground, of fish species, species, occurrence, diversity, composition, and production of fish that landed in landing port in 4 districts in Banten Province before tsunami occurrence. This data as baseline and indicators basis of technical management for and measure the successful management process and also the basis for rehabilitation and reconstruction after the tsunami.

\section{METHOD}

This research conducted in four landing port form fisheries that divide into 4 districts is Tangerang, Serang, Pandeglang, and Lebak. The fishing ground and landing port of fisheries where data record from fisherman at 2018 shown in the figure below.

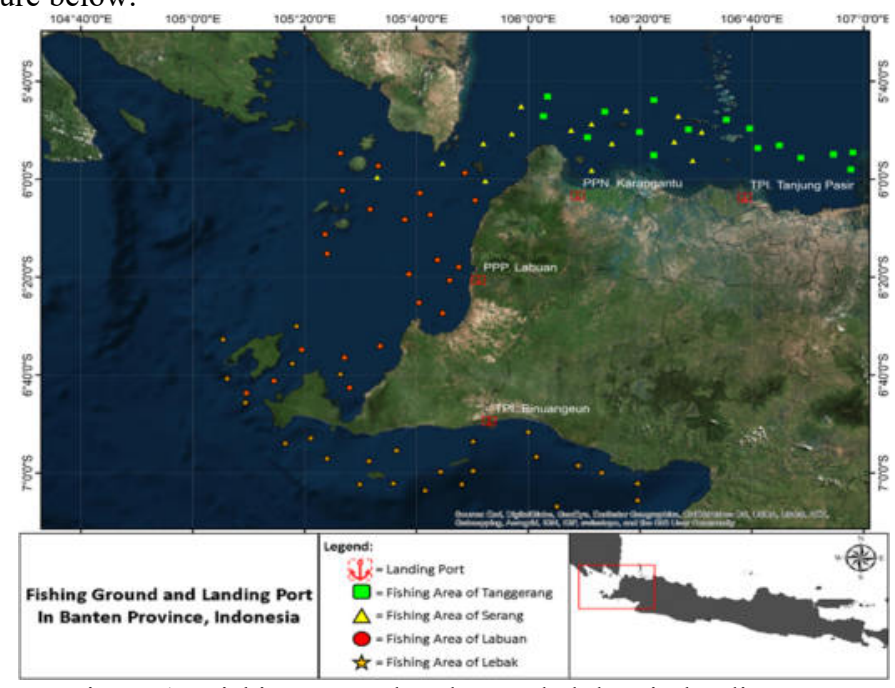

Figure 1. Fishing ground and recorded data in landing port

The data collected divided into two categories are directly collected in location, and some biology data collected in laboratories. Secondary data collected from the landing port or statistic agency in each district. Production data collected from 2003 to 2018 and biology data record in 2018. The data collected analyze by statistic descriptive for mapping in each species and diversity, ratio, production trend, biomass trend in each landing port. Statistic analyses used to check of difference between landing port particularly of diversity and production. This data also used as basic data of artisanal fisheries in Banten Sea before the tsunami disaster.

\section{RESULT AND DISCUSSION \\ Fishing Ground}

Banten province has an area of $8,651.20 \mathrm{~km} 2$ that surrounded by three main of the sea are the Java Sea in the north, the Sunda Strait in the West, and the Indian Ocean in the South. Fishing activities are generally carried out around the coast with a distance of between two to six miles of sea and belonging to the group of artisanal fishermen. The fishing activity actually is done in whole days in each location with differences characteristic of the sea.

According to Pomeroy et al (2010), this model is known as artisanal fisheries that operate in the short term by utilizing fish resources around coastal and marine ecosystems 
There are 5 (five) dominant fishing gear in Banten Province, which are classified into 5 (five) groups. The number and type of tools from 2009 to 2016 are explained in the following.

Table 1. Number of fishing gear for the period 2009-2016

\begin{tabular}{lrrrrrrrrr}
\hline \multirow{2}{*}{ Gear } & \multicolumn{8}{c}{ Number of gear (unit/year) } & \multirow{2}{*}{ Average (unit/year) } \\
\cline { 2 - 8 } & $\mathbf{2 0 0 9}$ & $\mathbf{2 0 1 0}$ & $\mathbf{2 0 1 1}$ & $\mathbf{2 0 1 2}$ & $\mathbf{2 0 1 3}$ & $\mathbf{2 0 1 4}$ & $\mathbf{2 0 1 5}$ & $\mathbf{2 0 1 6}$ & 1251.16 \\
\hline Trawl & 859 & 1398 & 1486 & 1431 & 1436 & & & 897 & 44.80 \\
Encircling Net & 29 & 43 & 46 & 49 & 57 & & & 10300 & 5278.50 \\
Gillnet & 3142 & 4113 & 4800 & 3850 & 5466 & & & 1634.75 \\
Hook & 1215 & 1488 & 1614 & 1780 & 1788 & 1836 & 1836 & 1521 & 2805.87 \\
Trap & 242 & 1037 & 543 & 966 & 5833 & 5505 & 5505 & 2816 & \\
\hline
\end{tabular}

Overall, during the last 10 years, the dominant fishing gears used were gillnet fishing gear, the equipment, and fishing rods. These types of fishing gear are the dominant fishing gear for demersal fish. In southern and northern waters Banten waters are dominated by fishing gills reaching $48 \%$ more. Next is a trap or trash unit which reaches $26 \%$, the fishing line reaches $15 \%$, and trawl reaches $11 \%$. The composition of each type of fishing gear is presented in the following figure

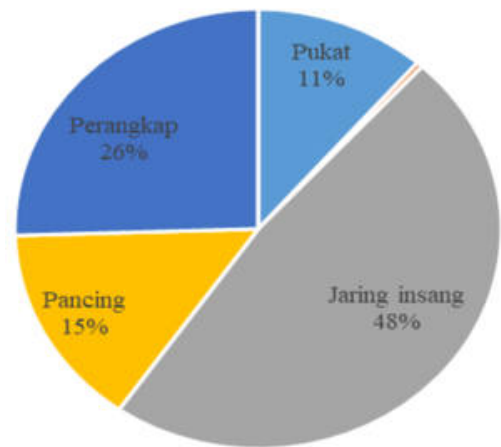

Figure 2 Composition of fishing gear 2009-2016

The catches of the fishing gear are demersal and small pelagic fish. All types of fish are classified as Indonesian native fish that have adapted in the Indonesian marine environment. In addition to fish, cephalopods, mollusks, and crustaceans (shrimp groups) were also found. The process of collecting data found at least 64 species of fish in the 4 districts which were recorded as follows

Table 1. List of species that record from four landing port in Banten

\begin{tabular}{|l|l|l|l|l|l|l|l|}
\hline \multirow{2}{*}{ No } & \multirow{2}{*}{ Local Name } & Scientific Nama & \multicolumn{3}{|c|}{ Landing Port } & \\
\hline 1 & Alu Alu & Sphyraena & Tangerang & Serang & Pandeglang & Lebak & \\
\hline 2 & Ayam Ayam & Abalistes stelaris & $\sqrt{ }$ & $\sqrt{ }$ & & & D \\
\hline 3 & Balak & Saurida & $\sqrt{ }$ & & & & D \\
\hline 4 & Baronang & Siganus & & $\sqrt{ }$ & & & D \\
\hline 5 & Baung & Macroterobargus sp & $\sqrt{ }$ & & & & D \\
\hline 6 & Bawal Hitam & Stromateus niger & & $\sqrt{ }$ & $\sqrt{ }$ & & D \\
\hline 7 & Bawal Putih & Pampus argenteus & & $\sqrt{ }$ & & & D \\
\hline 8 & Belanak & Mugil cephalus & & $\sqrt{ }$ & & & D \\
\hline 9 & Beloso & Glossogobius giuris & & $\sqrt{ }$ & & & D \\
\hline 10 & Bentong & Selar crumenophthalmus & & $\sqrt{ }$ & & & SP \\
\hline 11 & Beteta & Anyperodon & $\sqrt{ }$ & & & & D \\
\hline 12 & Biji Nangka & Upeneus & $\sqrt{ }$ & & $\sqrt{ }$ & & D \\
\hline 13 & Bilis & Engraulis grayi & $\sqrt{ }$ & & & & SP \\
\hline 14 & Cakalang & Katsuwonus pelamis & & & & $\sqrt{ }$ & LP \\
\hline 15 & Cendro & Tylosurus & & $\sqrt{ }$ & & SP \\
\hline 16 & Corak & Scarus sp & $\sqrt{ }$ & & & D \\
\hline 17 & Cucut & Centrophorus squamosus & & $\sqrt{ }$ & $\sqrt{ }$ & D \\
\hline 18 & Demang & Priacanthus tayenus & $\sqrt{ }$ & & & D \\
\hline 19 & Ekor Kuning & Caesio sp & & $\sqrt{ }$ & $\sqrt{ }$ \\
\hline 20 & Gerit & Pomadays maculatus & $\sqrt{ }$ & & & D \\
\hline
\end{tabular}




\begin{tabular}{|c|c|c|c|c|c|c|c|}
\hline \multirow[b]{2}{*}{ No } & \multirow[b]{2}{*}{ Local Name } & \multirow[b]{2}{*}{ Scientific Nama } & \multicolumn{4}{|c|}{ Landing Port } & \\
\hline & & & Tangerang & Serang & Pandeglang & Lebak & \\
\hline 21 & Gulamah & Johnius sp & & $\sqrt{ }$ & & & $\mathrm{D}$ \\
\hline 22 & Ikan sebelah & Pseudorhombus sp & & $\sqrt{ }$ & $\sqrt{ }$ & & $\mathrm{D}$ \\
\hline 23 & Japuh & Dussumieria acuta & $\sqrt{ }$ & $\sqrt{ }$ & & & $\mathrm{P}$ \\
\hline 24 & Julung-julung & Hemirhamphus sp & & & $\sqrt{ }$ & & $\mathrm{P}$ \\
\hline 25 & Kakap Merah & Lutjanus & $\sqrt{ }$ & $\sqrt{ }$ & $\sqrt{ }$ & $\sqrt{ }$ & $\mathrm{D}$ \\
\hline 26 & kakap putih & Lates calcarifer & & $\sqrt{ }$ & $\sqrt{ }$ & & $\mathrm{D}$ \\
\hline 27 & Kapasan & Gerres acuta & $\sqrt{ }$ & & & & $\mathrm{D}$ \\
\hline 28 & Kembung & Rastrelliger & $\sqrt{ }$ & $\sqrt{ }$ & $\sqrt{ }$ & $\sqrt{ }$ & $\mathrm{P}$ \\
\hline 29 & Kerapu & Plectropomus & $\sqrt{ }$ & $\sqrt{ }$ & $\sqrt{ }$ & $\sqrt{ }$ & $\mathrm{D}$ \\
\hline 30 & Kerong-kerong & Terapon therap & $\sqrt{ }$ & $\sqrt{ }$ & & & $\mathrm{D}$ \\
\hline 31 & Kuniran & Upeneus sp & $\sqrt{ }$ & $\sqrt{ }$ & & & $\mathrm{D}$ \\
\hline 32 & Kurisi & Nemipterus & $\sqrt{ }$ & $\sqrt{ }$ & $\sqrt{ }$ & & $\mathrm{D}$ \\
\hline 33 & Kuro & Polynemus & $\sqrt{ }$ & $\sqrt{ }$ & & & $\mathrm{D}$ \\
\hline 34 & Kuwe & Caranx sp & $\sqrt{ }$ & $\sqrt{ }$ & $\sqrt{ }$ & $\sqrt{ }$ & $\mathrm{D}$ \\
\hline 35 & Lape & Scarus ghobban & $\sqrt{ }$ & & & & $\mathrm{D}$ \\
\hline 36 & Layang & Decapterus sp & & $\sqrt{ }$ & $\sqrt{ }$ & $\sqrt{ }$ & $\mathrm{SP}$ \\
\hline 37 & Layaran & Istiophorus sp & & $\sqrt{ }$ & & $\sqrt{ }$ & LP \\
\hline 38 & Layur & Trichiurus sp & $\sqrt{ }$ & $\sqrt{ }$ & $\sqrt{ }$ & $\sqrt{ }$ & $\mathrm{D}$ \\
\hline 39 & Lemuru & Sardinella $s p$ & & $\sqrt{ }$ & $\sqrt{ }$ & & $\mathrm{P}$ \\
\hline 40 & Lencam & Lethrinus lentjam & & $\sqrt{ }$ & & & $\mathrm{D}$ \\
\hline 41 & Manyung & Arius sp & & $\sqrt{ }$ & $\sqrt{ }$ & & $\mathrm{P}$ \\
\hline 42 & Parang parang & Chirocnetrus dorab & $\sqrt{ }$ & $\sqrt{ }$ & & & $\mathrm{D}$ \\
\hline 43 & Pari & Dasyatis $s p$ & $\sqrt{ }$ & $\sqrt{ }$ & $\sqrt{ }$ & $\sqrt{ }$ & $\mathrm{D}$ \\
\hline 44 & Peperek & Leiognathus sp & $\sqrt{ }$ & $\sqrt{ }$ & $\sqrt{ }$ & $\sqrt{ }$ & $\mathrm{D}$ \\
\hline 45 & Sebelah & Psetodes erumei & $\sqrt{ }$ & & & & $\mathrm{D}$ \\
\hline 46 & Selar & Selaroides sp & $\sqrt{ }$ & $\sqrt{ }$ & $\sqrt{ }$ & & $\mathrm{P}$ \\
\hline 47 & Sembilang & Plotosus canius & & $\sqrt{ }$ & & & $\mathrm{D}$ \\
\hline 48 & Talang-talang & Scomberiodes sp & & $\sqrt{ }$ & & & LP \\
\hline 49 & Tembang & Sardinella fimbriata & & $\sqrt{ }$ & $\sqrt{ }$ & $\sqrt{ }$ & $\mathrm{SP}$ \\
\hline 50 & Tenggiri & Scomberomorus commersonii & & $\sqrt{ }$ & $\sqrt{ }$ & $\sqrt{ }$ & SP \\
\hline 51 & Tengkek & Megalaspis cordyla & $\sqrt{ }$ & $\sqrt{ }$ & $\sqrt{ }$ & & $\mathrm{SP}$ \\
\hline 52 & Teri & Stelophorus sp & $\sqrt{ }$ & $\sqrt{ }$ & $\sqrt{ }$ & $\sqrt{ }$ & $\mathrm{P}$ \\
\hline 53 & Tiga waja & Johnius trachycephalus & $\sqrt{ }$ & & $\sqrt{ }$ & & $\mathrm{D}$ \\
\hline 54 & Tongkol & Euthynuss $s p$ & & $\sqrt{ }$ & $\sqrt{ }$ & $\sqrt{ }$ & $\mathrm{P}$ \\
\hline 55 & Tuna & Thunnus sp & & & & $\sqrt{ }$ & $\mathrm{P}$ \\
\hline 56 & Others & Others fish & & & $\sqrt{ }$ & $\sqrt{ }$ & \\
\hline & Cephalopoda & & & & & & \\
\hline 57 & Cumi-Cumi & Loligo & & $\sqrt{ }$ & $\sqrt{ }$ & & \\
\hline 58 & Sotong & Sepina sp & & $\sqrt{ }$ & & & \\
\hline & Krustase & & & & & & \\
\hline 59 & Udang & Penaeus monodon & & $\sqrt{ }$ & & & \\
\hline 60 & Udang Lainnya & Penaeus sp & & & $\sqrt{ }$ & & \\
\hline 61 & Udang Putih & Penaeus merquiensies & & & $\sqrt{ }$ & & \\
\hline 62 & Rajungan & Portunus pelagicus & & $\sqrt{ }$ & & & \\
\hline & Mollusca & & & & & & \\
\hline 63 & Kerang & Anadara sp & & & $\sqrt{ }$ & & \\
\hline 64 & Remis & Meretrix meretrix & & & $\sqrt{ }$ & & \\
\hline
\end{tabular}

Note: $\sqrt{ }=$ recorded landed in the fishing port; $\mathrm{D}=$ demersal fish, $\mathrm{SP}=$ small pelagic fish, $\mathrm{LP}=$ large pelagic fish Diversity

Generally in Banten sea, found five groups of fish categories such as pelagic, demersal, cephalopods, crustaceans, and mollusk. Pelagic fish $36.4 \%$, demersal fishes $56.2 \%$, cephalopods $2.5 \%$, crustacea $3.3 \%$ and mollusk $1.7 \%$. The dominance of demersal fishes as an indicator of benthic seabed and fauna that need by fishes (Munadas et al, 
2015). Pelagic and demersal fish are found in all four locations, while cephalopods, crustose and mollusks are only recorded in the attack and are as clear as in the following figure

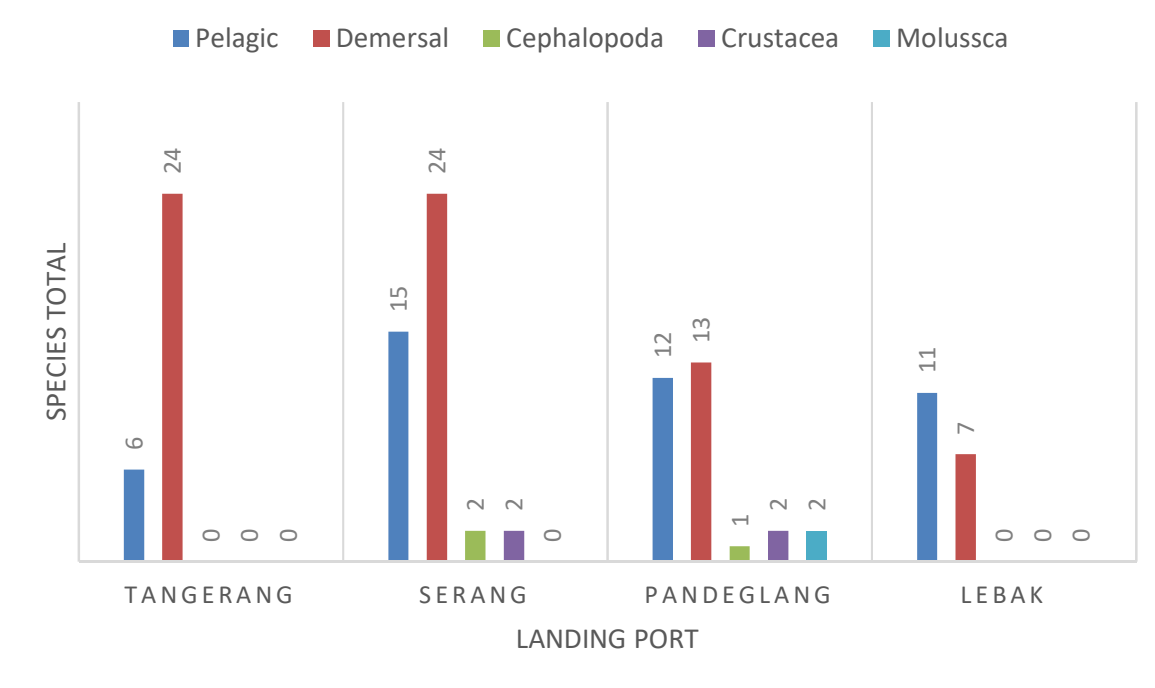

Figure 3. Comparison of species in four landing port in Banten

The northern waters of Banten are areas that have muddy and rocky characteristics and are relatively shallow water with characteristics of inland waters. While Serang and Pandeglang include transitional waters in the Sunda region which are affected by the effects of the Indian Ocean and the Natuna Sea and also some environmental influence such as water quality and another risk in the water body (Farriols, et al, 2015). So that in this region more species of fish are found from other locations. These two locations illustrate the transition area, where there are changes in the type of fish from the demersal dominant to the pelagic. Of the two main groups namely pelagic and demersal, patterns of change are like the following figure

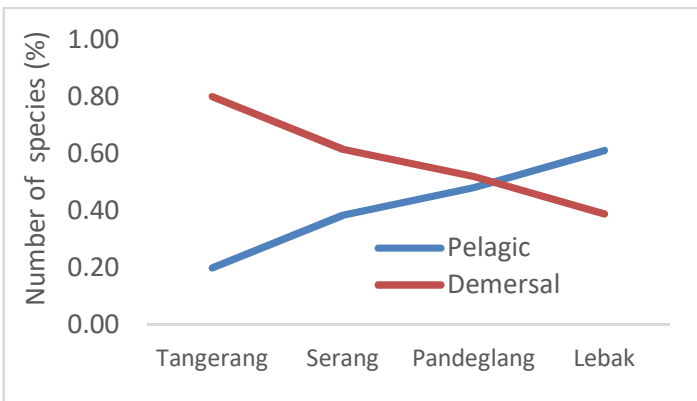

A

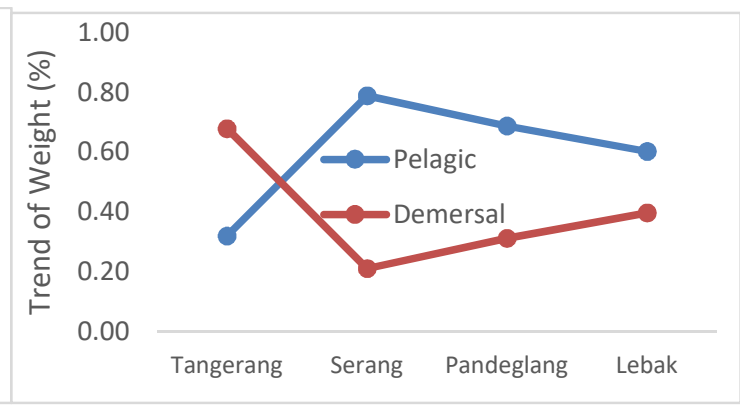

B

Figure 4. Comparison of number percentage (A) and weight (B) of pelagic and demersal fish

The composition of pelagic fish in Tangerang (20\%) Serang (38\%), Pandeglang (48\%) and Lebak $61 \%$ on the contrary for Demersal fish. This means that the ratio of demersal fish is reduced to oceanic waters and many dominance of pelagic (large and small pelagic) fish. Number, weight, and productivity are the main indicators to enhance production and productivity (Morgan et al, 2014).

The weight composition of pelagic fish in Tangerang (38\%), Serang (79\%), Pandeglang (69\%), and Lebak $(60 \%)$ in contrast to demersal fish. In general, the fish in the waters of Serang, Pandeglang, and Lebak is larger than the Tangerang pelagic fish. Sometimes weight and biomass data gathered use to predict and design a forecast model of fish stock (Ratz, et al, 2013).

\section{Production}

Production of pelagic fish reaches $58 \%$ and demersal $42 \%$, and mollusk, Crustacea, and cephalopod under $1 \%$. Production of pelagic fish highest in Lebak over than $93 \%$ of total production in Banten sea. This condition influence of large pelagic fish such as Thunnus sp and Scomberomorus and small pelagic fish such as Decapterus and Euthynus sp. The production composition is shown as the figure below. 


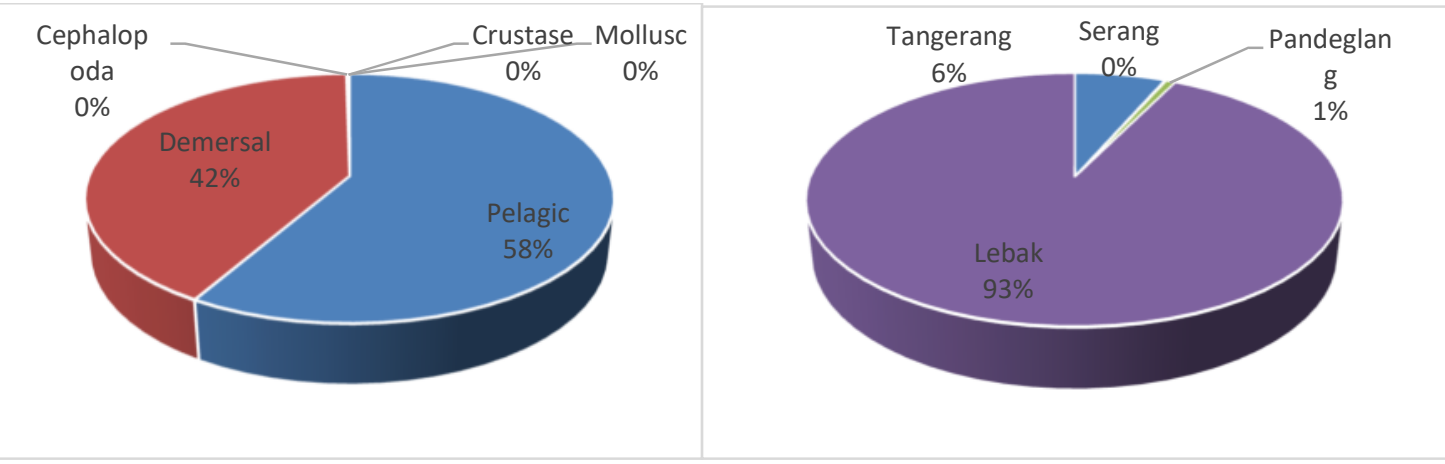

Figure 5. The composition of species in each taxa and landing port

Comparison between number and weight in each landing port shown that Serang the highest diversity but have the lowest productivity. But in Lebak landing port found low diversity and high productivity. It's mean that fisheries activity in Southern Banten better than northern Banten sea. According to Branc (2008), not all fisheries production will collapse 2048 due to policy, environmental, annual cycles, markets, and global trends, but still as small scale fisheries status (Carvalho et al, 2011).

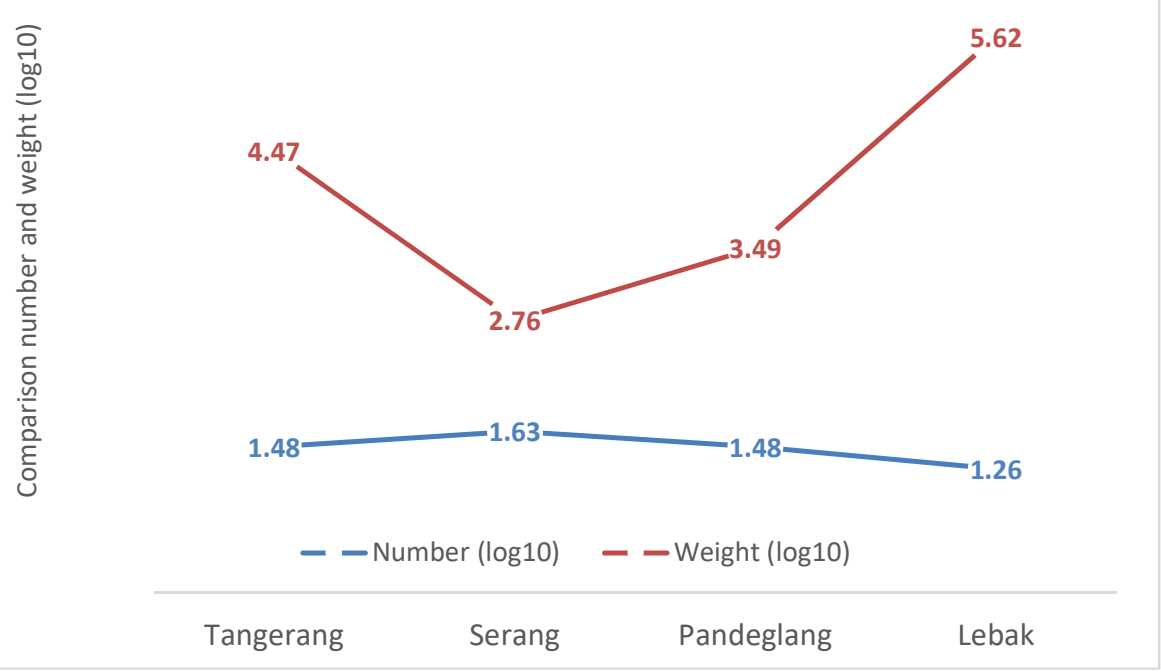

Figure 6. The Comparison number and weight species

\section{DISCUSSION}

Coastal fisheries activities in Banten sea consist of 2 major groups, are artisanal fisheries and industrial fisheries. However, artisanal fisheries are more dominantly than industrial fisheries as seen from the dominance of artisanal fishing such as gillnet, traps, and line. Performance fishing gear in southern and northern Banten sea shown by fishing fleet dominated by gillnet that reaches $42 \%$, trap about $30 \%$, line $18 \%$, and trawl about $10 \%$. Others fleet operate by a fisherman in this area under $10 \%$ of the total fishing fleet. Trawl and purse seine are widely used to catch demersal fish and skipjack tuna and mackerel fish in southern Banten.

The total catches were recorded 643 species of fish consisting of $87,5 \%$ fish, $3,125 \%$ cephalopods, $6,25 \%$ crustaceans, and 3,125\% mollusks. The northern part of Banten and parts of the west are predominantly demersal fish, and parts of western and southern are predominantly pelagic fish. Pandeglang region is an area that has demersal and pelagic high diversity. This diversity explains that the fishing area of Pandeglang is a transitional area between the of the Indian Ocean in the South and the Java Sea in the north. In addition, an important part that needs to be known is that the Pandeglang are close to the Krakatau volcano, which is always active and releases hot temperatures. The dominantly fish population recorded in Sunda strait known as coastal fish and have a close relation to environmental parameters (Ruijing, et al, 2010).

Although Pandeglang is a high contributor of pelagic and demersal biodiversity, overall it has low biomass. The biggest contribution of biomass is Lebak district, which is dominated by large pelagic fish such as skipjack, little tuna, and mackerel fish. Although with a low number of species, Lebak regency has a large production value as a representation of large pelagic fish from Ocean capture. 
The Krakatoa volcano eruption on 22 December 2018 which caused the collapse of a part of the mountain caused a "silent tsunami" and damage to the coastal area particularly in Serang, Pandeglang. Many fishing gears which are then damaged such as life net traps, and boat on the coastal area. In addition, because debris also causes an increase in turbidity of the waters and can affect the diversity of fish. For this reason, it is important to assess the condition of fisheries after the tsunami from the eruption of the Anak Krakatau volcano.

\section{CONCLUSION}

The fish diversity in Northern Banten sea particularly are dominantly recorded from Serang landing port, and then have the highest number than others port. But productivity in Southern Banten sea is the best than other landing port. It's mean the Banten sea in southern in good condition than the northern sea and it also influences the fishing intensity of artisanal fisheries. Impact of Krakatao eruption and tsunami potential to reduce or influence of fish biodiversity in Sunda strait. Important to check and evaluate fisheries activity after the tsunami of Krakatoa to ensure stock and diversity sustainability and fishing activity for the future.

\section{REFERENCE}

Branch TA, 2008. Not all fisheries will be collapsed in 2048. Marine Policy 32 (2008) 38-39.

Carvalho N, G Edward-Jones, E Isidro. 2011. Defining scale in fisheries: Small versus large-scale fishing operations in the Azores. Fisheries Research 109 (2011) 360-369. http://doi:10.1016/j.fishres.2011.03.006

Farriols MT, F Ordines, M Hidalgo, B Guijarro, E Massutí. 2015. N90 index: A new approach to biodiversity based on similarity and sensitive to direct and indirect fishing impact. Ecological Indicators 52 (2015) 245255. http://dx.doi.org/10.1016/j.ecolind.2014.12.009

Pomeroy R, L Garces, M Pido, G Silvestre. 2010. Ecosystem-based fisheries management in small-scale tropical marine fisheries: Emerging models of governance arrangements in the Philippines. Marine Policy 34 (2010) 298-308.

Samir Ibrahim Rizkalla, El Sayed Haroun Khamis Akel, Evelyn Ragheb. 2016. Biodiversity and fisheries of the non-target catch from bottom trawl, off Alexandria, Mediterranean Sea, Egypt. Regional Studies in Marine Science 3 (2016) 194-204. Elsevier

Mark J. Costello and Bill Ballantine. 2015. Biodiversity conservation should focus on no-take Marine Reserves 94\% of Marine Protected Areas allow fishing. Trends in Ecology \& Evolution, September 2015, Vol. 30, No. 9

Muntadas A., S Juan., M Demestre. 2015. Integrating the provision of ecosystem services and trawl fisheries for the management of the marine environment. Science of the Total Environment 506-507 (2015) 594-603. http://dx.doi.org/10.1016/j.scitotenv.2014.11.042

Morgan MJ, P.A.Shelton and R.M.Rideout. 2014. Varying components of productivity and their impact on fishing mortality reference points for Grand Bank Atlantic cod and American plaice. Fisheries Research 155 (2014) 64-73. http://dx.doi.org/10.1016/j.fishres.2014.02.019

Ratz H J. A. Charef A J. Abella., F Colloca, , A Ligas, A Manning and J. Lloret. 2013. A medium-term, stochastic forecast model to support sustainable, mixed fisheries management in the Mediterranean Sea. Journal of Fish Biology (2013) 83, 921-938. http://doi:10.1111/jfb.12236

Ruijing W, Z Feng, S Xiujuan, S Shan. 2010. Impacts of the variability of habitat factors on species composition of ichthyoplankton and distribution of fish spawning ground in the Changjiang River estuary and its adjacent waters. Acta Ecologica Sinica 30 (2010) 155-165. http://doi:10.1016/j.chnaes.2010.04.006

Worm, B., Hilborn, R., Baum, J.K., Branch, T.A., Collie, J.S., Costello, C., Fogarty, M.J., Fulton, E.A., Hutchings, J.A., Jennings, S., Jensen, O.P., Lotze, H.K., Mace, P.M., McClanahan, T.R., Minto, C., Palumbi, S.R., Parma, A.M., Ricard, D., Rosenberg, A.A., Watson, R., Zeller, D., 2009. Rebuilding global fisheries. Science 325 (5940), 578-585, http://dx.doi.org/10.1126/science.1173146. 